21 Nanni V, Uher R, Danese A. Childhood maltreatment predicts unfavorable course of illness and treatment outcome in depression: a meta-analysis. Am J Psychiatry 2012; 169: 141-51

22 Agnew-Blais J, Danese A. Childhood maltreatment and unfavourable clinical outcomes in bipolar disorder: a systematic review and meta-analysis. Lancet Psychiatry 2016; 3: 342-9.

23 Fisher $\mathrm{H}$, Hosang $\mathrm{G}$. Childhood maltreatment and bipolar disorder: a critical review of the evidence. Mind Brain 2010; 1: 75-85.

24 Grande I, Berk M, Birmaher B, Vieta E. Bipolar disorder. Lancet 2016; 387: 1561-72.

25 Correll CU, Detraux J, De Lepeleire J, De Hert M. Effects of antipsychotics, antidepressants and mood stabilizers on risk for physical diseases in people with schizophrenia, depression and bipolar disorder. World Psychiatry 2015: 14: $119-36$

26 Dell'Osso B, Glick ID, Baldwin DS, Altamura AC. Can long-term outcomes be improved by shortening the duration of untreated illness in psychiatric disorders? a conceptual framework. Psychopathology 2013; 46: 14-21.

27 Leverich GS, McElroy SL, Suppes T, Keck Jr PE, Denicoff KD, Nolen WA, et al. Early physical and sexual abuse associated with an adverse course of bipolar illness. Biol Psychiatry 2002; 51: 288-97.

28 Maina G, Bechon E, Rigardetto S, Salvi V. General medical conditions are associated with delay to treatment in patients with bipolar disorder. Psychosomatics 2013; 54: 437-42.

29 Bai Y-M, Su T-P, Li C-T, Tsai SJ, Chen MH, Tu PC, et al. Comparison of proinflammatory cytokines among patients with bipolar disorder and unipolar depression and normal controls. Bipolar Disord 2015; 17: 269-77.

30 Baumeister D, Russell A, Pariante CM, Mondelli V. Inflammatory biomarker profiles of mental disorders and their relation to clinical, social and lifestyle factors. Soc Psychiatry Psychiatr Epidemiol 2014; 49: 841-9.

31 Scott KM, Von Korff M, Angermeyer MC, Benjet C, Bruffaerts R, de Girolamo G, et al. Association of childhood adversities and early-onset mental disorders with adult-onset chronic physical conditions. Arch Gen Psychiatry 2011; 68 838-44.

32 Danese A, Tan M. Childhood maltreatment and obesity: systematic review and meta-analysis. Mol Psychiatry 2014; 19: 544-54.

33 Felitti V. Relationship of childhood abuse and household dysfunction to many of the leading causes of death in adults: the Adverse Childhood Experiences. Am J Prev Med 1998; 14: 245-58.

34 Edwards VJ, George W, Holden PD, Vincent J, Felitti PD, Robert F, et al. Relationship between multiple forms of childhood maltreatment and adult mental health in community respondents: results from the adverse childhood experiences study. Am J Psychiatry 2003; 160: 1453-60.

35 Dube SR, Fairweather D, Pearson WS, Felitti VJ, Anda RF, Croft JB, Cumulative childhood stress and autoimmune diseases in adults. Psychosom Med 2009: 71: 243-50.

36 Reuben A, Moffitt TE, Caspi A, Belsky DW, Harrington H, Schroeder F, et al. Lest we forget: comparing retrospective and prospective assessments of adverse childhood experiences in the prediction of adult health. J Child Psycho Psychiatry 2016; 57: 1103-12.

37 Newbury JB, Arseneault L, Moffitt TE, Caspi A, Danese A, Baldwin JR, et al. Measuring childhood maltreatment to predict early-adult psychopathology: comparison of prospective informant-reports and retrospective self-reports. J Psychiatr Res 2018; 96: 57-64.

38 Chen L, Magliano DJ, Zimmet PZ. The worldwide epidemiology of type 2 diabetes mellitus - present and future perspectives. Nat Rev Endocrinol 2011; 8: 228

39 Frasch K, Larsen JI, Cordes J, Jacobsen B, Olrik S, Jensen W, et al. Physical illness in psychiatric inpatients: comparison of patients with and without substance use disorders. Int J Soc Psychiatry 2013; 59: 757-64.
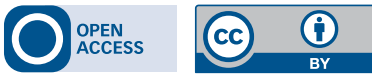

\title{
Extra
}

\section{Sir Walter Raleigh: deliberate self-harm in the Tower of London, 1603}

\section{Greg Wilkinson}

Sir Walter Raleigh (circa 1554-1618) - a landed gentleman, writer, poet, soldier, politician, courtier, spy and explorer - is one of the most notable and controversial figures of the first Elizabethan era. A favourite of Elizabeth I, shortly after her death on 24 March 1603 he was accused of plots against her successor James I. Raleigh was arrested on 19 July 1603 and imprisoned in the Tower of London.

Sir John Peyton, Lieutenant of the Tower, wrote to Lord Robert Cecil, one of Raleigh's judges, on 21 July 1603

'... Raleigh still maintained his innocence "but with a mind the most dejected that ever I saw." Two days later, he again spoke of Raleigh's "so strange a dejected mind" and said that "his fortitude is [not] competent to support his grief."'

Cecil described Raleigh's behaviour on 27 July 1603 to his confidant, Sir Thomas Parry, Ambassador in France, in a letter dated 4 August 1603:

... yet one afternoon, whilst divers of us were in the Tower, examining some of these prisoners, he attempted to have murdered himself: whereof when we were advertised, we came to him and found him in some agony, seeming to be unable to endure his misfortunes, and protesting innocency, with carelessness of life; and, in that humour, he had wounded himself under his right pappe, but no way mortally, being, in truth, rather a cut than a stab, and now very well cured both in body and mind.

Raleigh wrote an impassioned letter to his wife 'immediately after he had given himself the wound in the Tower':

... I cannot live to think how I am derided, to think of the expectation of my enemies, the scorns I shall receive, the cruel words of lawyers, the infamous taunts and despites, to be made a wonder and a spectacle! Oh, death! hasten thee unto me, that thou mayest destroy the memory of these, and lay me up in dark forgetfulness! Oh, death! destroy my memory, which is my tormentor; my thoughts and my life cannot dwell in one body.'

The Lieutenant wrote again to Cecil on 30 July 1603:

... Sr Walter Rawley his hurte wyll be whn [within] these two days pfectly hoole; he doth styll contyneue pplexed as you leffte hym.... his spirites ar exceeding muche declined, hisgrowne passionate in lamentatyon and sorrowe 